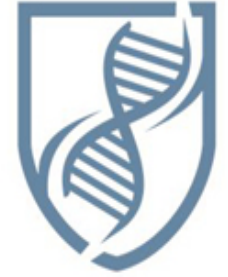

Journal of Bioscience and Applied Research

\section{JBAAR}

WWW.JBAAR.ORG

\title{
Anticancer activity of Morus nigra on human breast cancer cell line (MCF-7): the role of fresh and dry fruit extracts
}

\author{
Ahmed A. ${ }^{1}$, Ali M. ${ }^{1}$, El-Kholie E. ${ }^{1}$, El-Garawani I. ${ }^{2 *}$ and Sherif N. ${ }^{1}$ \\ ${ }^{1}$ Department of Nutrition and Food Science, Faculty of Home Economics,Menoufia University, Menoufia, Egypt \\ ${ }^{2 *}$ Department of Zoology, Faculty of Science, Menoufia University, Menoufia, Egypt.
}

(Corresponding author-email: dr.garawani@yahoo.com)

\begin{abstract}
Black mulberry (Morus nigra L.) has a long history of medicinal use in folk medicine. In this study, in vitro anticancer properties of fresh and dry black mulberry (BM) ethanolic extracts on breast adenocarcinoma cell line (MCF-7) were investigated. Cytotoxic effect of both extracts was investigated by neutral red uptake method and the $\mathrm{IC}_{50}$ was assessed. The morphological changes, apoptosis and/or necrosis, were detected by Giemsa staining and acridine orange/ethidium bromide dual fluorescent staining methods, in addition to DNA fragmentation assay by gel electrophoresis and comet assay. Mitotic index was evaluated in MCF-7 groups to investigate the antiproliferative potential of fresh and dry BM extracts. Furthermore, micronucleus and other nuclear abnormalities were also investigated. BM extracts administration gave significant $(p<0.05)$ morphological
\end{abstract}

evidence of apoptosis and increased cell death after 48 hours more than that of 24 hours-treated MCF-7 cells among fresh and dry extract groups. DNA analysis after $24 \mathrm{~h}$ of BM extracts treated groups has no fragmentation while apoptosis is generated after $48 \mathrm{~h}$ showing more fragmentation in fresh BM groups. The mitotic index records were significantly decreased in dose and time dependent manner showing the better antiproliferative effect with fresh extract treatments. DNA single strand breaks were also increased among the treatment groups at dose and time dependent manner with the best results with fresh extract. It can be concluded that black mulberry fruit is a considerable source of health dietary supplement and its integration for pharmaceutical industries has to be in concern.

Keywords: Morus nigra, MCF-7, Apoptosis, Micronucleus test, Comet assay and Mitotic index.

\section{Introduction}

Black mulberry (Morus nigra L.), belonging to the Moraceae family, native to southwestern Asia. It has a long history of Chinese folk medical use (Pawlowska et al., 2008 and Kutluet al., 2009). Black mulberry (BM) is one of the medicinal plants that have a great value in many treatments. Mulberry fruits as deep-colored fruits are good sources of phenolics, including anthocyanins and other flavonoids, and carotenoids (Kutluet al., 2009 and Song et al., 2009). Anthocyanin pigment molecules are a subclass of flavonoids. They are responsible for the red, purple, and blue colors observed in many plants (Nikkhah et al., 2010 and Kostic et al., 2013). Much progress has been made in identifying possible causes of cancer (Kirkegaard et al., 2010). Recently, an attempt to overcome these carcinogenic agents using natural materials has paid a great concern. Breast cancer is one of the most common malignancies all over the world. Human breast adenocarcinoma (MCF-7) cell line has become a prominent model system for the study of breast cancer as it relates to the susceptibility of the cells to apoptosis. Anthocyanins are thought to contribute to the nutritive value of fruits and berries due to their antioxidative, anti-carcinogenic, anti-inflammatory, and anti-angiogenic properties (Igarashi and Inagaki, 1991). Anthocyanins, the main active ingredient of mulberry, 
could decrease the in vitro invasiveness of cancer cells (Chen et al., 2006). It could inhibit the growth and metastasis of B16-F1 cells (Huang et al., 2008), induced apoptotic death in gastric carcinoma cells (Huang et al., 2011). Anthocyanins and phenolic acids have antiproliferative effect on various cell lines including MCF7 cells (Heredia et al., 2015).The present work investigated , in vitro, anticancer properties of fresh and dry black mulberry (BM) ethanolic extracts on breast adenocarcinoma cell line (MCF-7).

\section{Materials and Methods}

\subsection{Plant materials}

Black mulberry fruits were obtained from local markets, Shanawan, Menuofia Governorate, Egypt. BM fruits were identified by a taxonomist, Faculty of Agriculture, Menufia University, Egypt.

\subsection{Preparation of black mulberry fruits ethanolic} extract

Both fresh and dried fruits (50g of each) were extracted with $10 \mathrm{x}(\mathrm{w} / \mathrm{v})$ of $70 \%$ ethanol. The mixture was filtered, evaporated in rotary evaporator (Buchi, France) until the constant weight was reached. The obtained ethanolic extracts of mulberry fruits was kept at $-20^{\circ} \mathrm{C}$ until used.

\subsection{In vitro anticancer study on $\mathrm{MCF}-7$}

\subsubsection{Cells maintenance}

Human breast cancer cell line (MCF-7) was purchased from (VACSRA), Giza, Egypt. Cells were maintained in complete growth medium [RPMI 1640 medium supplemented with $10 \%$ fetal bovine serum (FBS) and $1 \%$ penicillin (100 U/ml)/streptomycin (100 $\mu \mathrm{g} / \mathrm{ml})] .5 \times 10^{5}$ cells were grown in each T25 culture flask containing $7 \mathrm{ml}$ of complete growth medium to reach $70 \%$ confluency at $37^{\circ} \mathrm{C}$, and then the treatments were added in triplicates. All culture reagents were obtained from (Lonza) supplier, Egypt.

\subsubsection{Determination of tumor cells viability and counts}

The visualization of MCF-7 cells viability was done according to trypan blue staining method (Berry et al., 1991). The concentration of cells per $\mathrm{ml}$ was determined using haemocytometer and they were calculated using the following calculations:

Cells $/ \mathrm{ml}=10^{4} \mathrm{x}$ (Average count per square) $\mathrm{x}$ (Dilution factor).

\subsubsection{Study design}

MCF-7 cultured flasks were divided into five groups as follow: Group I: untreated cells; Group II: Fresh black mulberry extract (FBME) (100 $\mu \mathrm{g} / \mathrm{ml})$; Group III: FBME (300 $\mu \mathrm{g} / \mathrm{ml})$; Group IV: Dried black mulberry extract (DBME) (100 $\mu \mathrm{g} / \mathrm{ml})$ \& Group V: DBME $(300 \mu \mathrm{g} / \mathrm{ml})$.

\subsubsection{Neutral red uptake assay}

The assay was performed according to the protocol described by Siddiqui et al. (2010). Post treatment, cells were washed with (PBS; $0.01 \mathrm{M}$; pH 7.4), and $40 \mu \mathrm{g} / \mathrm{ml}$ of neutral red containing medium were added. After $3 \mathrm{~h}$ of incubation, the supernatant was removed, and the cells were washed with a solution of $0.5 \%$ formaldehyde and $1 \%$ calcium chloride. Subsequently, a solution of $1 \%$ acetic acid and $50 \%$ ethanol was added, and the dye was extracted for $10 \mathrm{~min}$.
The absorbance was then read at a wavelength of $540 \mathrm{~nm}$. Cytotoxicity was calculated and $\mathrm{IC}_{50}$ was assessed. The experiment was conducted in triplicate.

\subsubsection{Giemsa staining}

Cells were smeared on a glass slide and air-dried. The smears were fixed in (3 parts methanol: 1 part glacial acetic acid) for 5 min. Cells were washed with PBS for 1 min then stained in Geimsa solution for 15 minutes and washed with PBS. Two hundred cells were examined (400 $\mathrm{x}$ ) using light microscope (Olympus BX 41, Japan) and digitally photographed (Thippeswamy and Salimath, 2006).

2.3.6. Acridine orange/ ethidium bromide dual fluorescent staining

Cells from the control and treated groups were smeared on a glass slide and air-dried. Smears were fixed by freshly-prepared 3:1 (v/v) methanol : glacial acetic acid for 10 minutes then they were hydrated with PBS for 1 minute and stained with a mixture (1:1) of acridine orange $(50 \mu \mathrm{g} / \mathrm{ml})$ /ethidium bromide $(5 \mu \mathrm{g} / \mathrm{ml})$ solutions for 5 minutes. Cells were immediately washed with PBS and examination was done using fluorescent microscope (Olympus BX 41, Japan). Two hundred of cells per group were evaluated (400x) and the damaged (apoptotic and necrotic) cells were recorded according to the affinity and pattern of nuclear fluorescent staining, and then representative photos were digitally photographed (ElGarawani., 2015).

\subsubsection{Micronucleus test}

Cells were grown on cover slips and the treatments were applied after reaching 70\% confluency. After the desired treatment period, cells were fixed in 95\% methanol for 5 min then stained with 5\% (Geimsa / May-Grünwald) for $10 \mathrm{~min}$. Cells were washed twice with PBS then 300 cells were examined in each sample for micronucleus, binucleated and nuclear budding evidence according to the criteria of Tolbert et al. (1992) using bright field microscope (Olympus BX 41, Japan) and representative photos were digitally captured.

\subsubsection{Total genomic DNA extraction and apoptosis detection}

DNA extraction and detection of apoptosis (DNA fragmentation assay) were done according to "salting out extraction method" of Aljanabi and Martinez (1997) with some modifications by Hassab El-Nabi and Elhassaneen (2008). Cells were incubated in lysing buffer two hours at $37^{\circ} \mathrm{C}$ then; proteins were precipitated using $4 \mathrm{M} \mathrm{NaCl}$. The resultant supernatant was transferred to a new tube then DNA was precipitated using cold isopropanol. The pellets of nucleic acids were washed with $70 \%$ ethyl alcohol. The pellets were resuspended in TE buffer and were incubated with loading mix $(0.1 \%$ RNase + loading buffer), and then loaded directly into $1.8 \%$ normal melting electrophoretic grade agarose in $1 \mathrm{X}$ Tris borate EDTA buffer. The apoptotic bands of DNA fragmentation appeared and located at 180 bp and its multiples 360, 540 and 720 bp against thirteen bands of DNA marker (100-3000 bp). The intensity of DNA apoptotic bands were measured by (Image J software) as a maximum optical density values. 


\subsubsection{Comet assay}

Alkaline single-cell gel electrophoresis (comet assay) was performed according to Singh et al. (1988). Briefly, cells were embedded into low melting point agarose gels on microscope slides and immersed in lysis buffer (2.5 M NaCl, $100 \mathrm{mM}$ EDTA and $10 \mathrm{mM}$ Tris, $\mathrm{pH}$ 10.0) with freshly added 1\% Triton X-100 (Sigma) and $10 \%$ DMSO for $1 \mathrm{~h}$ at $4{ }^{\circ} \mathrm{C}$. Subsequently, the slides were incubated in freshly made alkaline buffer (300 mM NaOH and $1 \mathrm{mM}$ EDTA, $\mathrm{pH}>13$ ) for $20 \mathrm{~min}$ at $4{ }^{\circ} \mathrm{C}$. An electric current of $300 \mathrm{~mA}$ and $25 \mathrm{~V}$ was applied for $15 \mathrm{~min}$. The slides were then neutralized (0.4 M Tris, $\mathrm{pH}$ 7.5), Then they were stained with ethidium bromide. Cells were visualized using fluorescence microscope (Olympus BX 41, Japan), and representative images were photographed. More than 100 randomly selected cells were examined for severity of DNA damage as comet fragmentation length. The results were divided as normal with no tail, damage with migrated tail not more than the diameter of the nucleus and strong damage with no distinct nucleus.

\subsubsection{Chromosomal preparation and mitotic index} assessment

For the analysis of MCF-7 chromosomes, colcemid $(10 \mu \mathrm{g} / \mathrm{ml})$ was added to the cells and left 2 hours, then cells were harvested and resuspended in hypotonic solution $(0.56 \% \mathrm{KCl})$ at $37{ }^{\circ} \mathrm{C}$ for 20 minutes, fixed with freshly-prepared 3:1 (v/v) methanol : glacial acetic acid. Fixed cells were resuspended and they were dropped onto glass slides and left to air-dry. The slides were stained with $3 \%(\mathrm{w} / \mathrm{v})$ Giemsa in phosphate buffer (Evans, 1987). Cells were examined (400x) under light microscope (Olympus BX 41, Japan) then the representative photomicrographs were captured (100x) using digital camera. The frequency of mitotic index was estimated in 500 cells for each group according to the following formula:

Mitotic index $(\mathrm{MI})=$ (Number of dividing cells/ Total examined cells) x100.

\subsection{Statistical analysis}

Data were presented as mean \pm standard error $(\mathrm{M}$ $\pm \mathrm{SE}$ ). Comparisons were made between the untreated and treated groups were statistically analyzed using Duncan's Multiple Range Test, $(p<0.05)$ were considered positive.

\section{Results}

\subsection{Evaluation of cytotoxicity using neutral red uptake assay}

The inhibition of MCF-7 cells growth rates was observed after both extracts administration as more effectiveness of fresh extract than dry one in dose dependent manner with no effect of treatments exposure time. The recorded $\mathrm{IC}_{50}$ were $575 \pm 15$ and $900 \pm 25 \mu \mathrm{g} / \mathrm{ml}$ for fresh and dry extracts respectively after $24 \mathrm{~h}$ and $48 \mathrm{~h}$.

3.2. Morphological changes after Giemsa staining method in MCF-7 cells treated with black mulberry extracts

The results of morphological changes revealed that fresh black mulberry extract was significantly $(p<0.05)$ exerted antitumor activities on MCF-7 cells than that of dried black mulberry extract after 48 hours while a little antitumor effect was observed among two types of extracts after 24 hours. Cytological analysis of all treated groups of MCF-7 cells using Giemsa staining method indicated typical apoptotic morphology of membrane blebbing when compared to the untreated cells Figure (1) and Table (1).

Table (1): Morphological changes in MCF-7 cells after Giemsa staining for treated and untreated groups.

\begin{tabular}{ccc|cc}
\cline { 2 - 5 } & \multicolumn{2}{c}{ 24h } & \multicolumn{2}{c}{ 48h } \\
& \%Dead & \%Apoptotic & \%Dead & \%Apoptotic \\
\cline { 2 - 5 } Control & $5 \pm 0.4$ & $0.6 \pm 0.5$ & $6.1 \pm 1.7$ & $1.0 \pm 0.9$ \\
$\mathbf{1 0 0} \boldsymbol{\mu g} / \mathbf{m l}($ FBME) & $32 \pm 3.0^{*}$ & $5.6 \pm 1.0^{*}$ & $15.0 \pm 2.0^{*}$ & $40.0 \pm 2.5^{*}$ \\
$\mathbf{3 0 0} \boldsymbol{\mu g} / \mathbf{m l}($ FBME) & $49 \pm 4.1^{*}$ & $6.3 \pm 1.0^{*}$ & $18.0 \pm 1.0^{*}$ & $37.6 \pm 1.2^{*}$ \\
$\mathbf{1 0 0} \boldsymbol{\mu g} / \mathbf{m l}($ DBME) & $19 \pm 4^{*}$ & $15.0 \pm 0.9^{*}$ & $16.3 \pm 2.1^{*}$ & $21.7 \pm 2.0^{*}$ \\
$\mathbf{3 0 0} \boldsymbol{\mu g} / \mathbf{m l}$ (DBME) & $28 \pm 1.0^{*}$ & $13.0 \pm 1.7^{*}$ & $20.3 \pm 2.0^{*}$ & $29 \pm 1.0^{*}$ \\
\hline
\end{tabular}

* Significant difference at ( $p<0.05)$ compared with control group. FBME: fresh black mulberry extract and DBME: dry black mulberry extract. 


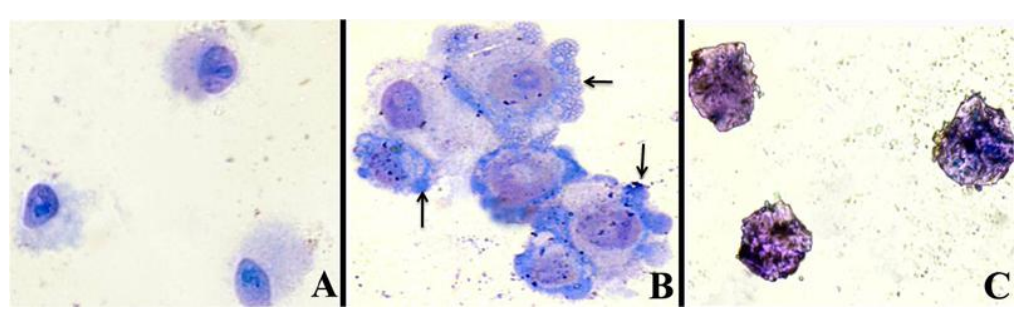

Figure (1): representative photomicrographs of Giemsa- stained MCF-7 cells showing morphological changes under light microscope (400 x). Where (A): normal control cells, (B): blebbing cytoplasm as a feature of apoptosis (arrows) and (C): dead cells.

3.3. Morphological changes after acridine orange/ ethidium bromide fluorescent staining

The formation of apoptotic bodies and nuclear condensation with bright orange color which are the characteristic features of apoptosis after acridine orange/ ethidium bromide staining was significantly $(p<0.05)$ observed among all treated groups of MCF-7 cells with dose and time dependant values as shown in Figure (2) and Table (2). While the untreated control cells showed intact nuclear architecture.

Table (2): Morphological changes in MCF-7 cells after acridine orange/ ethidium bromide staining for treated and untreated groups.

\begin{tabular}{|c|c|c|c|c|}
\hline & \multicolumn{2}{|c|}{$24 \mathrm{~h}$} & \multicolumn{2}{|c|}{$48 \mathrm{~h}$} \\
\hline & \%Dead & \%Apoptotic & \%Dead & \%Apoptotic \\
\hline Control & $4.0 \pm 1.0$ & $0.3 \pm 0.1$ & $5.3 \pm 1.5$ & $2.0 \pm 1.0$ \\
\hline $100 \mu \mathrm{g} / \mathrm{ml}($ FBME) & $61.0 \pm 1.0^{*}$ & $0.2 \pm 0.3$ & $46.0 \pm 2.0^{*}$ & $27.7 \pm 1.5^{*}$ \\
\hline $300 \mu \mathrm{g} / \mathrm{ml}(\mathrm{FBME})$ & $70.6 \pm 1.5^{*}$ & $0.5 \pm 0.3^{*}$ & $39.7 \pm 2.1^{*}$ & $32.3 \pm 2.5^{*}$ \\
\hline $100 \mu \mathrm{g} / \mathrm{ml}(\mathrm{DBME})$ & $32.4 \pm 2.1^{*}$ & $0.7 \pm 0.5^{*}$ & $31.6 \pm 1.5^{*}$ & $6.0 \pm 1.0^{*}$ \\
\hline 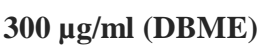 & $64.9 \pm 2.6^{*}$ & $0.3 \pm 0.2$ & $55.6 \pm 3.1^{*}$ & $7.6 \pm 1.2^{*}$ \\
\hline
\end{tabular}

* Significant difference at $(p<0.05)$ compared with control group. FBME: fresh black mulberry extract and DBME: dry black mulberry extract.
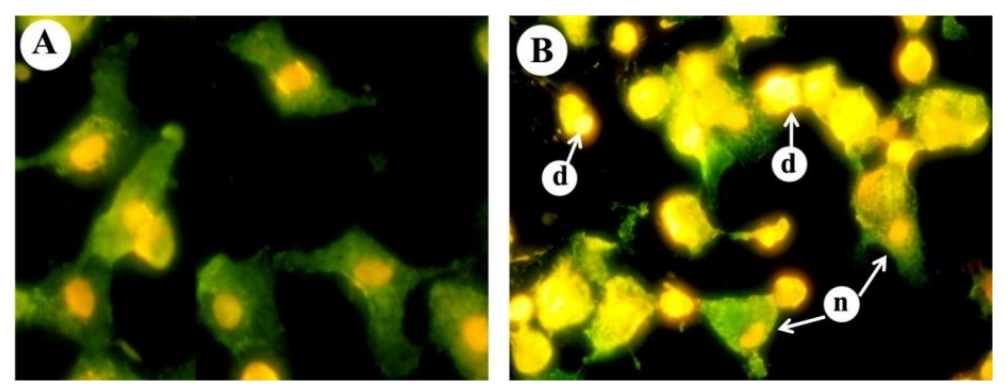

Figure (2): Representative photomicrograph for MCF-7 cells nuclear morphology after acridine orange / ethidium bromide fluorescent staining, (400x). Where (A): normal control cells, (B): showing dead cells with high intensity of fluorescence, where d: dead and n: normal. 


\subsection{Micronucleus and other nuclear abnormalities assay}

The frequency of micronucleus, nuclear budding and binucleated cells induction in MCF-7 cells after BM extracts treatment was significantly $(p<0.05)$ elevated among all treated groups at dose and time dependant manner (Table 3). Among the abnormalities observed budding nuclei were the most frequent after 24h. While after $48 \mathrm{~h}$ of treatment exposure, binucleated cells were the most frequent (Figure 3).

Table (3): Micronucleus and other nuclear abnormalities in MCF-7 cells for treated and untreated groups.

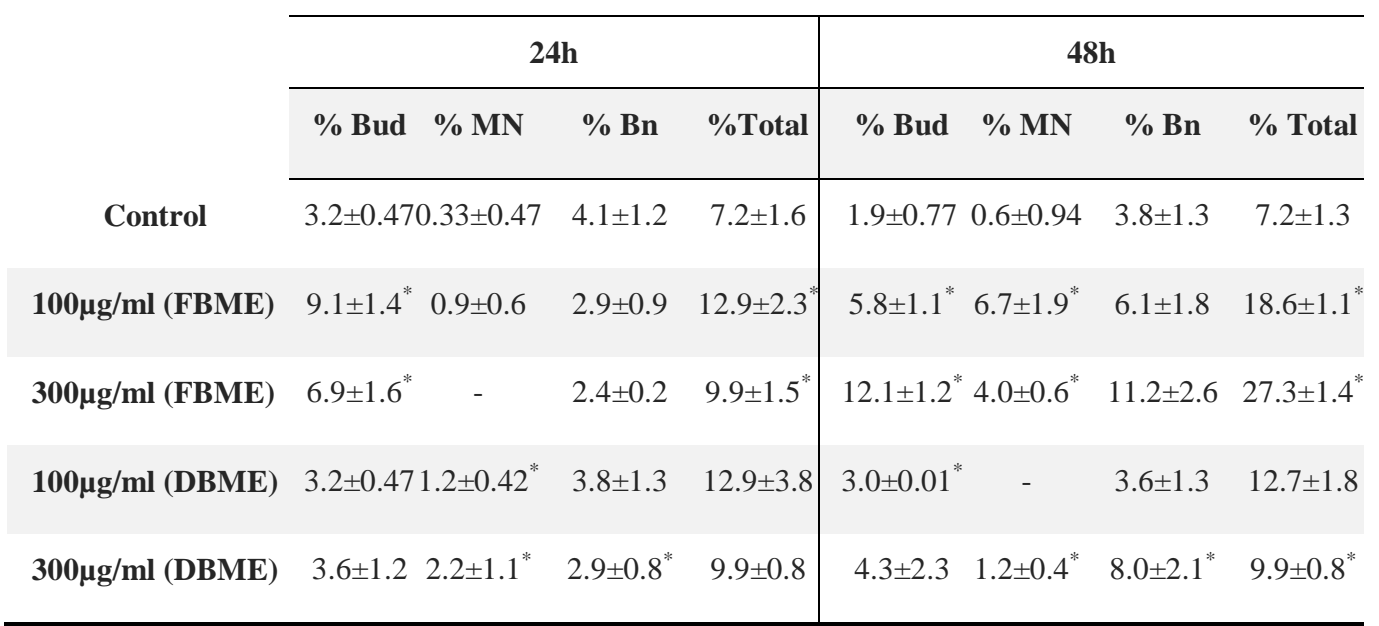

* Significant difference at $(p<0.05)$ compared with control group. FBME: fresh black mulberry extract and DBME: dry black mulberry extract.

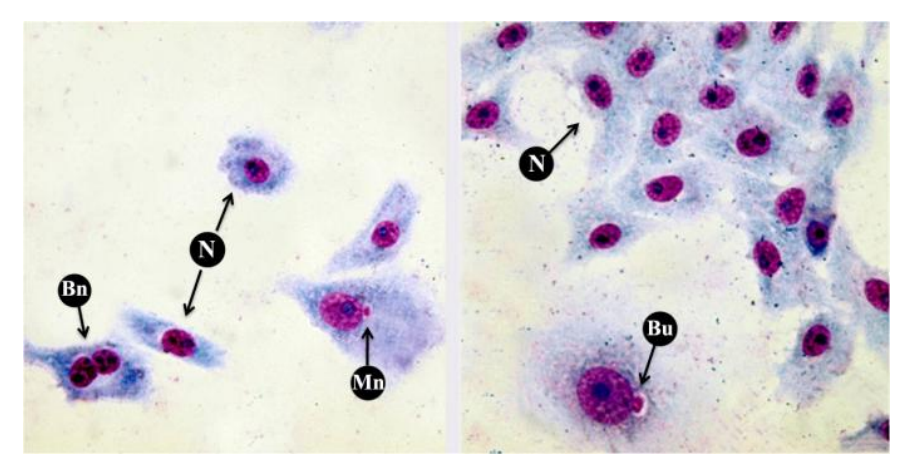

Figure (3): Representative photomicrograph for MCF-7 cells micronucleus, nuclear budding and binucleated occurrence after Geimsa / May-Grünwald staining, (400x). Where (N): normal cells, (Bn): binucleated cell, (Bu): nuclear budding and (Mn): micronucleus.

\subsection{Total genomic DNA fragmentation in MCF-7 cells treated with black mulberry extracts}

DNA from control MCF-7 cells was found to be intact (undamaged) as seen in (lane 1 , Figure 4\&5) with no release of DNA. The results of 24 hours treatment revealed no DNA damage was occurred (Figure 4), while the DNA from all treatments groups after 48 hours indicated the presence of DNA damage and marked by the migration of released fragmented DNA (Figure 5).

The administration of fresh black mulberry extract (lane 2\&3) was significantly the best treatment which induced sever DNA damage which observed as a late stage of apoptosis with laddering pattern of DNA fragmentation after $48 \mathrm{~h}$ of treatment when compared with control group. Dry black mulberry extract showed DNA damage less than that of fresh black mulberry extract as shown in (lane 4\&5) Table (4) and Figures (4,5). 
Table (4): Optical density of fragmented DNA in treated and untreated MCF-7 cells after $48 \mathrm{~h}$.

\begin{tabular}{|c|c|c|c|c|}
\hline & 180bp & $360 \mathrm{bp}$ & $540 \mathrm{bp}$ & 720bp \\
\hline Control & - & - & - & - \\
\hline $100 \mu \mathrm{g} / \mathrm{ml}(\mathrm{FBME})$ & $32.8 \pm 8.9$ & $44.3 \pm 8.4$ & $95.6 \pm 13$ & $127.5 \pm 7.5$ \\
\hline $300 \mu \mathrm{g} / \mathrm{ml}(\mathrm{FBME})$ & $65.7 \pm 10.7$ & $68.7 \pm 12.6$ & $116.0 \pm 4.3$ & $156.3 \pm 23.7$ \\
\hline 100 pg/ml(DBME) & $25.6 \pm 7.6$ & $26.9 \pm 2.6$ & $35.0 \pm 4.4$ & $52.2 \pm 12.8$ \\
\hline 300 pg/ml (DBME) & $36.7 \pm 4.0$ & $15.7 \pm 6.8$ & $19.9 \pm 5.7$ & $35.7 \pm 9.8$ \\
\hline 1 & 3 & 4 & $\mathbf{M}$ & \\
\hline & & & 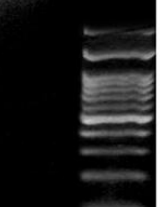 & $\begin{array}{l}3000 \\
2000 \\
1500 \\
500\end{array}$ \\
\hline
\end{tabular}

Figure (4): Representative digital photograph of total genomic DNA electrophoresis shows the effect of 24 hours treatments on MCF-7 cells. Where, lane: 1 resembles control MCF-7 cells group and lanes: 2-5 resemble fresh black mulberry treated cells $100 \mu \mathrm{g} / \mathrm{ml}$, fresh black mulberry treated cells $300 \mu \mathrm{g} / \mathrm{ml}$, dry black mulberry treated cells $100 \mu \mathrm{g} / \mathrm{ml}$

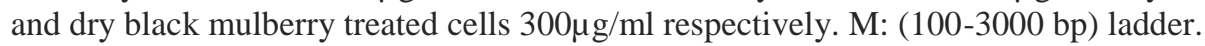

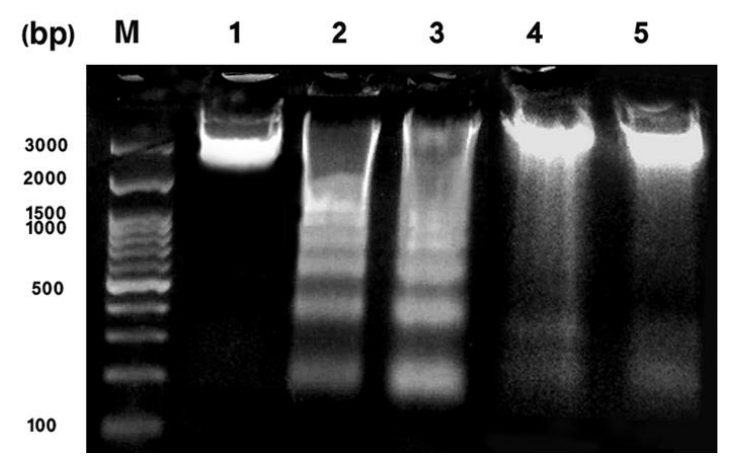

Figure (5): Representative digital photograph of total genomic DNA electrophoresis shows the effect of 48 hours of treatments on MCF-7 cells. Where, lane: 1 resembles control MCF-7 cells group and lanes: 2-5 resemble fresh black mulberry treated cells $100 \mu \mathrm{g} / \mathrm{ml}$, fresh black mulberry treated cells $300 \mu \mathrm{g} / \mathrm{ml}$, dry black mulberry treated cells $100 \mu \mathrm{g} / \mathrm{ml}$ and dry black mulberry treated cells $300 \mu \mathrm{g} / \mathrm{ml}$ respectively. M: (100-3000 bp) ladder.

\subsection{DNA single strand breaks in MCF-7 cells treated with black mulberry extracts}

The results of comet assay revealed that the presence of three forms of cells to be evaluated. They were normal (N), damaged (D) and strong damaged cells (SD) with fan-like tail. The DNA damage was increased, as well as, DNA tail migration length and intensity were increased when compared to intact undamaged normal cells (Figure 6). The recorded cells showed slightly increase in two forms of damaged cells percentage after
24 hours of both extracts administrations when compared to control group (Table 6). Moreover, after 48 hours of treatments, the results recorded significant $(p<0.05)$ elevation in the percentage of DNA-damaged cells especially with fresh extract treatments rather than that of dry one (Table 6). 
Table (6): Comet assay in MCF-7 cells for treated and untreated groups.

\begin{tabular}{|c|c|c|c|c|}
\hline & \multicolumn{2}{|c|}{$24 \mathrm{~h}$} & \multicolumn{2}{|c|}{$48 \mathrm{~h}$} \\
\hline & $\%$ damage & $\begin{array}{l}\text { \% strong } \\
\text { damage }\end{array}$ & $\%$ damage & $\begin{array}{c}\text { \% strong } \\
\text { damage }\end{array}$ \\
\hline Control & $8.5 \pm 1.5$ & - & $10.5 \pm 1.5$ & $4.0 \pm 1.1$ \\
\hline 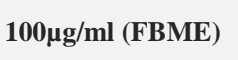 & $15.1 \pm 5.2^{*}$ & $21.3 \pm 3.7^{*}$ & $15.1 \pm 4.5$ & $32.6 \pm 3.7^{*}$ \\
\hline 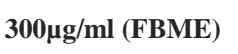 & $12.2 \pm 4.7^{*}$ & $22.4 \pm 5.7^{*}$ & $5.4 \pm 2.4$ & $40.3 \pm 9.0^{*}$ \\
\hline 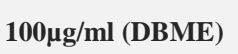 & $5.2 \pm 0.35$ & $26.1 \pm 5.5^{*}$ & $5.0 \pm 2.0$ & $26.3 \pm 5.1^{*}$ \\
\hline 300 $\mu \mathrm{g} / \mathrm{ml}$ (DBME) & $4.7 \pm 2.5$ & $25.3 \pm 3.3^{*}$ & $6.3 \pm 1.75$ & $35.4 \pm 6.4^{*}$ \\
\hline
\end{tabular}

* Significant difference at $(p<0.05)$ compared with control group. FBME: fresh black mulberry extract and DBME: dry black mulberry extract.
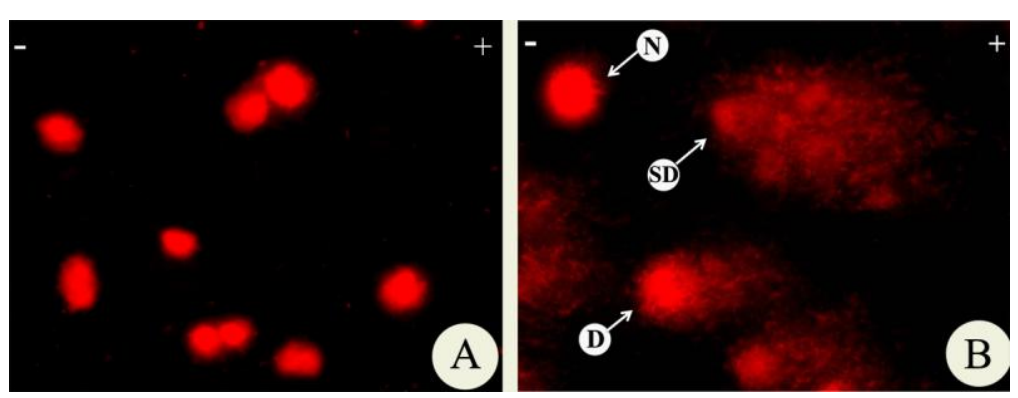

Figure (6): Representative photomicrograph for MCF-7 cells (400x) after comet assay technique. Where A: control untreated cells and B: treated cells showing grades of DNA damage (N: normal, D: damaged and SD: strong damaged nuclei).

\subsection{Mitotic index frequency in MCF-7 cells treated with} black mulberry extracts

The mitotic indexes were significantly $(p<0.05)$ inhibited in dose and time dependent manner when compared with control divided cells among all treatments illustrating the more effectiveness of antiproliferative properties of fresh extract than the dry one. They recorded

the highest inhibition of mitotic frequency with (300 $\mu \mathrm{g} / \mathrm{ml}$ ) fresh black mulberry extract after 48 hours of treatment. While, $(100 \mu \mathrm{g} / \mathrm{ml})$ dry black mulberry extract gave the lowest inhibition index (Table 7).

Table (7): Mitotic index in MCF-7 cells for treated and untreated groups.

\begin{tabular}{cc|c}
\cline { 2 - 3 } & \multicolumn{2}{c}{$\%$ Mitotic index } \\
\cline { 2 - 3 } Control & $\mathbf{2 4 h}$ & $\mathbf{4 8 h}$ \\
\cline { 2 - 3 } $\mathbf{1 0 0} \mathbf{~ g / m l ~ ( F B M E ) ~}$ & $20.4 \pm 2.7^{*}$ & $13.4 \pm 3.3^{*}$ \\
$\mathbf{3 0 0} \mathbf{~ g / m l ~ ( F B M E ) ~}$ & $4.2 \pm 1.6^{*}$ & $1.3 \pm 3.1^{*}$ \\
$\mathbf{1 0 0} \mathbf{~} \mathbf{g} / \mathbf{m l}$ (DBME) & $21.6 \pm 2.3^{*}$ & $16.7 \pm 2.9^{*}$ \\
$\mathbf{3 0 0} \mathbf{~ g g / m l ~ ( D B M E ) ~}$ & $8.8 \pm 2.1^{*}$ & $3.6 \pm 2.1^{*}$ \\
\hline
\end{tabular}

* Significant difference at $(p<0.05)$ compared with control group. FBME: fresh black mulberry extract and DBME: dry black mulberry extract. 


\section{Discussion}

Despite the fact that many tumors initially respond to chemotherapy, breast cancer cells can survive and gain resistance to the chemotherapy (Campbell et al., 2001). Additionally, the non selectivity of chemical drugs has to be considered and trials for alternative medications have to be paid more concern. Accumulating evidences suggests that berry fruits may have potential for cancer prevention that may be due to their contents of macro- and micronutrients and the large number of bioactive phytochemicals (Ramos, 2008 and Huang et al., 2010). Moreover, due to their antioxidant properties, consumption of polyphenolic-rich foods play a role in the prevention of certain types of cancer and other diseases related to aging (Borbalanet al., 2003). These compounds are classified as flavonoids, tannins, phenolic acids and their analogues, and others depending on their chemical structures (Ramos, 2008; Huang et al., 2010). Flavonoid antioxidants have been demonstrated to exhibit anticancer effects against several epithelial cancers (Jiang et al., 2000). The relationship between natural polyphenols, apoptosis and cancer was identified by studding chemopreventive and/or chemotherapeutic ability of these compounds against cancer. One such important group of berry phytochemicals is anthocyanins. Anthocyanins are known to acts as anticarcinogenic agents against several cancers (Bishayee et al., 2011). Moreover, anthocyanin and other phenolic compounds of BM extracts may have potent effects, including anticancer with antioxidant, antiinflammatory, and chemoprotective properties (Morse et al., 1993; Middleton et al., 2000, Li et al., 2013). Pure anthocyanins suppressed the growth of HCT116 colon and HS578T breast cell lines by G2/M cell cycle arrest and apoptosis (Chen et al., 2005; Yun et al., 2009). Apoptosis was identified as the major mode of anthocyanin-induced cell death (Chen et al., 2005; Seeram et al., 2006; Srivastava et al., 2007). The data of researches demonstrated proapoptotic effect of anthocyanins on numerous cancer cell lines (Katsube et al., 2003; Olsson et al., 2004; Chen et al., 2005; Seeram et al., 2006, Forester and Waterhouse, 2010). Also, anthocyanins induced apoptosis in MCF-7 cells as increased the amounts of oligonuceosomal-sized fragmentation (Devi et al., 2011).

In this study, the results of apoptotic anticancer properties were proved by evaluation of morphological changes and DNA fragmentation of MCF-7 treated with BM extracts. The results are in parallel to the proapoptotic properties of several pure anthocyanins and anthocyanin-rich extracts from berries on multiple cell types through both apoptotic pathways (Seeram et al., 2006 and Afaq et al., 2007).

Cytotoxicity test using neutral red method and mitotic index evaluated results of treated groups were in parallel with previous studies that reported high antiproliferative properties of mulberry juices (Seeram et al., 2006; Huang et al., 2008 and Zhang et al., 2011). These activities may be due to the contents of phenolic compounds that have been considered to be responsible for the various health benefits including cancer prevention (Huang et al., 2008).

\section{References}

Afaq F, Syed DN, Malik A, Hadi N, Sarfaraz S and Kweon MH (2007) Delphinidin, an anthocyanidin in pigmented fruits and vegetables, protects human $\mathrm{HaCaT}$ keratinocytes and mouse skin against UVB-mediated oxidative stress and apoptosis. J Invest Dermatol. 127 (1): 222-232.

Aljanabi SM and Martinez I (1997) Universal and rapid salt-extraction of high quality genomic DNA for PCR based techniques. Nucleic Acids Res. 25(22):46924693.

Berry MN, Edwards AM and Barritt GJ (1991) Isolated hepatocytes preparation, properties and applications. In: Burdon, R.H.; van Knippenberg, P. H., Ed.,.Laboratory techniques in biochem mol boil. 21: 1-49.

Bishayee A Mbimba T and Thoppil RJ HáznagyRadnai ESipos PDarvesh ASFolkesson HGHohmann J (2011) Anthocyanin rich black currant (Ribes nigrum L.) extract affords chemoprevention against diethylnitrosamine-induced hepatocellular carcinogenesis in rats. J. Nutr. Biochem. 22: 1035-46.

Borbalan AMA, Zorro L, Gullen DA and Barroso CG (2003) Study of the polyphenol content of red and white grape varieties by liquid chromatographymass spectrometry and its retalionship to antioxidant power. J. Chrom. A, 1012: 31-38.

Campbell RA, Bhat-Nakshatri P, Patel NM, Constantinidou D, Ali S and Nakshatri H (2001) Phosphatidylinositol 3 - kinase / AKT - mediated activation of estrogen receptor alpha. A new model for anti-estrogen resistance. J. Biol. Chem. 276: 9817-9824.

Campbell RA, Bhat-Nakshatri P, Patel NM, Constantinidou D, Ali S and Nakshatri H (2001) Phosphatidylinositol/3-kinase/Akt-mediated activation of estrogen receptor a: a new model for anti-estrogen receptor resistance, J. Biol. Chem. 276: 9817-9824.

Chen PN, Chu SC, Chiou HL, Chiang CL, Yang SF and Hsieh YS (2005) Cyanidin 3-glucoside and peonidin 3-glucoside inhibit tumor cell growth and induce apoptosis in vitro and suppress tumor growth in vivo. Nutr. Cancer. 53: 232-243.

Chen PN, Chu SC, Chiou HL, Kuo WH, Chiang CL and Hsieh YS (2006) Mulberry anthocyanins, cyanidin 3-rutinoside and cyaniding 3-glucoside, exhibited an inhibitory effect on the migration and invasion of a human lung cancer cell line. Cancer Letters. 235: 248-259.

Devi PS Kumar MS and Das SM (2011) Evaluation of antiproliferative activity of red sorghum bran anthocyanin on a human breast cancer cell line (mcf-7). Int. J. Breast Cancer, 2011 (ID891481): 6-12.

El-Garawani IM (2015) Ameliorative effect of Cymbopogon citratus extract on cisplatin-induced genotoxicity in human leukocytes. J of BiosciAppl Res. 1 (6): 304-310. 
Evans EP (1987) Karyotyping and sexing of gamets, embryos, fetuses and in situ hybridization to chromosomes. In: Mammalian Development. A Practical approach, Non K.M(Ed) pub. IRL, Press Oxford pp. 93100.

Forester SC and Waterhouse AL (2010) Gut metabolites of anthocyanins, gallic acid, 3-O-methylgallic acid, and 2,4,6-trihydroxybenzaldehyde, inhibit cell proliferation of Caco-2 cells. J. Agric. Food Chem. 58: 5320-5327.

Hassab El-Nabi SE and Elhassaneen YA (2008): Detection of DNA damage, molecular apoptosis, and production of home-made ladder by using simple technique. Biotechnology, 7 (3): 514- 522.

Hemmati AA, Jalali MT, Rashidi I and Kalantar HT (2010) Impact of aqueous extract of black mulberry (Morus nigra) on liver and kidney funcion of diabetic mice. Jundishapur j. nat. pharm. prod. 5 (1): 18-25.

Heredia JB, Muy-Rangel MD, Valdez-Torres JB, Serna-Saldívar SO and Gutiérrez-Uribe JA (2015) Anthocyanins and phenolic acids of hybrid and native blue maize (Zea mays L.) extracts and their antiproliferative activity in mammary (MCF7), liver (HepG2), colon (Caco2 and HT29) and prostate (PC3) cancer cells D. A. Urias-Lugo. Plant Foods Hum Nutr. 70 (2): 193-199.

Huang HP, Chang YC, Wu CH, Hung $\mathrm{CN}$ and Wang CJ (2011) Anthocyanin-rich Mulberry extract inhibit the gastric cancer cell growthinvitroand xenograft mice by inducing signals of p38/p53 and c-jun. Food Chem. 129: 1703-1709.

Huang HP, Shih YW, Chang YC, Hung CN and Wang CJ (2008) Chemoinhibitory effect of mulberry anthocyanins on melanoma metastasis involved in the Ras/PI3K pathway. J. Agric. Food Chem. 56: 9286-9293.

Huang WU, Cai ZY and Zhang J (2010) Natural phenolic compounds from medicinal herbs and dietary plants: potential use for cancer prevention. Nutr. Cancer 62 (1): 1- 20.

Igarashi K and Inagaki K (1991) Effects of the major anthocyanin of wild grape (Vitiscoignetiae) on serum lipid levels in rats. Agric. Biol. Chem. 55 (1): 285 287 .

Jiang C, Agarwal R and Lu J (2000) Antiangiogenic potential of a cancer chemopreventive flavonoid antioxidant, silymarin: inhibition of key attributes of vascular endothelial cells and angiogenic cytokine secretion by cancer epithelial cells. Biochem. Biophys. Res. Commun., 276: 371-378.

Katsube N, Iwashita K, Tsushida T, Yamaki K and Kobori M (2003) Induction of apoptosis in cancer cells by bilberry (Vacciniummyrtillus) and the anthocyanins. J. Agric. Food Chem. 51: 68-75.

Kirkegaard H, Johnsen NF and Christensen J (2010) Association of adherence to life style recommendations and risk of colorectal. Brit Med. J. 26 (341): 5504.

Kostic DA, Dimitrijevic DS, Mitic SS, Mitic MN, Stojanovic GS avdZivanovic AV (2013) Phenolic content and antioxidant activities of fruit extracts of Morus nigra L (Moraceae) from Southeast Serbia. Trop J of Pharm Res. 12 (1): 105-110.

Kutlu N, Terzi R, Tekeli C, Senel G, Battal P and Kadioglu A (2009) Changes in anatomical structure and levels of endogenous phytohormones during leaf rolling in Ctenanthesetosa. Turk J Biol. 33: 115-122.

Li WJ, Ma CL, Sun WF and Zhou J (2013) Antioxidant activity of extracts from Morus nigra Linn. Food Res Develop. 34 (3): 11-13.

Middleton E, Kandaswami Jr C and Theoharides TC (2000) The effects of plant flavonoids on mammalian cells: implications for inflammation, heart disease and cancer, Pharmacol. Rev. 52: 673-751.

Morse MA and Stoner GD (1993) Cancer chemoprevention principles and prospects. Carcinogenesis. 14: 1743-1746.

Nikkhah E, Khaiamy M, Heidary R and Azar AS (2010) The effect of ascorbic acid and $\mathrm{H}_{2} \mathrm{O}_{2}$ treatment on the stability of anthocyanin pigments in berries. Turk $\mathrm{J}$ of Biol, 34 (1): 47-53.

Olsson ME, Gustavsson KE, Andersson S, Nilsson A and Duan RD (2004) Inhibition of cancer cell proliferation in vitro by fruit and berry extracts and correlations with antioxidant levels. J. Agric. Food Chem. 52 : 7264-7271.

Pawlowska AM, Oleszek W and Braca A (2008) Quali-quantitative analyses of flavonoids of Morus nigra L. and Morus alba L. (Moraceae) fruits. Agric. Food Chem. 56 (9): 3377-3380.

Ramos S (2008) Cancer chemoprevention and chemotherapy. Dietary polyphenols and signalling pathways. Mol. Nutr. Food Res.52: 507-526.

Seeram NP, Adams LS, Zhang Y, Lee R, Sand D, Scheuller HS, Heber D (2006) Blackberry, black raspberry, blueberry, cranberry, red raspberry, and strawberry extracts inhibit growth and stimulate apoptosis of human cancer cells in vitro. Agric. Food Chem. 54 (25): 9329-9339.

Siddiqui MA, Kashyap MP, Kumar V, AlKhedhairy AA, Musarrat J, Pant AB (2010) Protective potential of trans-resveratrol against 4-hydroxynonenal induced damage in PC12 cells Toxicol In Vitro. 6: 15921598.

Singh NP, McCoy MT, Tice RR and Schneider EL (1988) A simple technique for quantitation of low levels of DNA damage in individual cells. Exp. Cell Res. 175: 184-191.

Song W, Wang HJ, Bucheli P, Zhang P, Wei DZ and Lu YH (2009) Phytochemical profiles of different mulberry (Morus sp.) species from China. Agric. Food Chem. 57 (19): 9133-9140.

Srivastava A, Akoh CC, Fischer J and Krewer G (2007) Effect of anthocyanin fractions from selected cultivars of Georgia-grown blue berries on apoptosis and phase II enzymes. J. Agric. Food Chem. 55: 3180-3185.

Thippeswamy G and Salimath BP (2006) Curcuma aromatic extract induces apoptosis and inhibits 
angiogenesis in Ehrlich ascites tumour cells in vivo. mySCIENCE. 1(1): 79-92.

Tolbert PE, Shy CM, Allen JW. (1992) Micronuclei and other nuclear anomalies in buccal smears: methods development. Mutat Res. 271: 69-77.

Yun JM, Afaq F, Khan N and Mukhtar H (2009) Delphinidin, an anthocyanidin in pigmented fruits and vegetables, induces apoptosis and cell cycle arrest in human colon cancer HCT116 cells. Mol. Carcinog. 48: 260-270.

Zhang Z, Knobloch TJ, Seamon LG, Stoner GD, Cohn DE, Paskett ED, Fowler JM and Weghorst CM (2011) A black raspberry extract inhibits proliferation and regulates apoptosis in cervical cancer cells. Gynecol. Oncol, 123: 401-406. 